\title{
Teologia a partir do vácuo - sobre dois textos de Dostoievski: Meditação diante do corpo de Maria Dimitrievna e A Dócil
}

\author{
Theology from the vacuum - based on two works by Dostoyevsky: \\ Meditation about the body of Maria Dimitrievna and A gentle creature.
}

Jimmy Sudário Cabral*

\begin{abstract}
Resumo
O artigo analisa dois textos de Dostoievski, o primeiro, "Meditação sobre o corpo de Maria Dimitrievna", redigido em 16 de abril de 1864, diante do cadáver de sua primeira esposa. É um dos raros textos onde Dostoievski escreve em primeira pessoa sobre suas convicções religiosas. A cena do corpo frio e inerte reflete a impotência da vida diante da mecânica impiedosa da natureza, tema que será recorrente nos futuros romances do autor, como em O Idiota, onde Dostoievski traduz o terrível sentimento de incerteza e repulsa diante da experiência da morte. No segundo texto, $A$ Dócil, encontramos uma reflexão que se aproxima, surpreendentemente, da confissão pessoal que encontramos em sua Meditação. Nele Dostoievski descreve os pensamentos de um marido que anda de um lado para o outro do quarto, onde estão os restos mortais da esposa, que cometera suicídio atirando-se de uma janela com um ícone preso a mão. Nos dois textos, nos deparamos com o Dostoievski homem e o Dostoievski artista, portador de uma sensibilidade que traduz uma consciência religiosa e trágica acerca dos limites da natureza e da razão.
\end{abstract}

Palavras-chave: Dostoievski; religião; morte; trágico.

\begin{abstract}
This article analyzes two texts of Dostoievski, the first one, Meditation about the body of Maria Dimitrievna, wrote on April 16, 1864, in front of the corpse of his first wife. It is one of rare texts that Dostoievski writes using the first person to talk about religious convictions. The scene of the cold and inert body reflects the impotence of life in face of the nature's relentless mechanics, theme that will be recurred in future novels of the author, like in The Idiot, where Dostoievski translates the terrible feeling of uncertainty and repulse in face of the death experience. In the second text, A gentle creature, we find a reflection that approaches surprisingly, the personal confession that we find in his Meditation. On it, Dostoievski describes the thoughts of a husband that walks from one side to the other in the bedroom, where the mortal remains of his wife, who has committed suicide by throwing herself through a window with an icon stuck on her hand. In both texts, we encounter how the man Dostoieveski and the artist Dostoievski, holder of a sensibility that translates a religious and tragic consciousness about the limits of nature and reason.
\end{abstract}

Keywords: Dostoyevsky; religion; death; tragic.

Artigo recebido em 27 de maio de 2014 e aprovado em 23 de junho de 2015.

* Doutor em Teologia e Ciências da Religião. Professor no Departamento e no Programa de Pós-graducação em Ciência da Religião da Universidade Federal de Juiz de Fora. País de origem: Brasil. E mail: sudarioc@hotmail.com 


\section{Introdução}

Le caractere transitoire de l'être témoigne que la seule force divine qui domine l'existence, c'est la mort.

Paul Evdokimov

Não encontramos na grandeza da obra Dostoievski uma idéia positiva do bem, compreendido dentro dos quadros de um vocabulário filosófico-religioso ou teológico, que seja capaz de oferecer um sentido cosmológico ou moral para a vida. Uma abordagem de suas obras precisa ter como ponto de partida a clareza de que a sua weltanschauung religiosa parte da constatação da perda dos fundamentos metafísicos e dogmáticos do cristianismo operados pela crítica moderna da religião. É de uma agonia que reconheceu a superação de uma cosmologia religiosa [proclamadora de um mundo organizado pela presença divina] que nascerá os seus conflitos espirituais, dos quais - a partir de uma poderosa dialética espiritual - ele extrairá o material que encontramos em suas tragédias. Dostoievski não pode ser considerado um teólogo, mas em sua escritura, sempre mergulhada nos temas da existência, encontramos os movimentos de um especialista da alma e dos seus abismos, um artista que soube traduzir os mundos movediços de uma consciência moderna e das suas aporias niilistas. O consciente fracasso em expor uma imagem concreta do bem, decorrente dos seus inúmeros esforços em construir um "personagem positivo", acompanhou-o na arquitetura de todas as suas obras. Em sua correspondência com Apollon Maikov, no primeiro trimestre de 1870, Dostoievski confessou a inquietude que movia o seu desejo de criar "uma figura majestosa, positiva, santa" (DOSTOIEVSKI, 2000, p. 572), e esta ansiedade o acompanhou por toda a vida e deu forma ao processo de gestação do caráter de todos os seus santos. L. A. Zander considerou que o mal ocupou em suas obras um lugar muito mais considerável do que o bem (ZANDER, 1946, p. 10), e uma leitura atenta do seu corpus literário torna evidente a fraqueza e a timidez dos seus raros e milagrosos acenos de virtude. Como reconheceu Zander, "existem mesmo aqueles 
que vão até o ponto de insinuar que Dostoievski jamais possuiu uma noção do bem e que ele contentou-se, neste domínio, com alguns truísmos, conscientemente introduzidos para não tornar-se suspeito de niilismo moral - uma espécie de proteção atrás da qual se abrigou a fim de dissimular o vazio absoluto de sua alma" (Ibid, p.10). O fato é que a intuição do negativo percorreu a vastidão dos seus escritos, e seu deslocamento das seguranças de uma religião positiva, bem como dos racionalismos que sustentaram as seguranças modernas, fez de sua literatura uma das expressões mais acabadas do espírito trágico moderno. Albert Camus considerou que Dostoiévski representou uma forma de sensibilidade que traduziu radical e incontornavelmente a perda de um mundo ordenado. Para ele, seus "heróis se interrogam sobre o sentido da vida", e é "nisso que eles são modernos: não temem o ridículo" (CAMUS, 1994, p. 142). Dessa forma, ele representa essa perda da totalidade que abateu a história do pensamento filosófico e religioso, e, que através de uma experiência de sofrimento, colocou em questão todo espírito "estóico" que reconheceu o divino no mundo, experimentado como um cosmos ordenado, concebido como ordem, beleza e medida.

$\mathrm{O}$ advento do negativo acontece quando uma subjetividade reconhece-se completamente deslocada da totalidade da vida, experimentando uma completa oposição à "serenidade do homem teórico" (CHIRPAZ, 1998, p. 100), e imersa em um sofrimento que nenhuma teodiceia poderia aplacar. A consciência da singularidade da própria existência, que se descobre imersa na imensidão de um mundo coberto pelo sofrimento e se desprende das formas de sentido de uma teodiceia religiosa ou racionalista, expressou-se na radicalidade da dor da existência de um homem "que mirou com olhar cortante a ação destrutiva da assim chamada história universal, assim como da crueldade da natureza" (NIETZSCHE, 1992, p. 55). O completo deslocamento de uma consciência trágica da voz a uma experiência de perda de mundo e a uma inquietude que não permite nenhuma forma de repouso. O que François Chirpaz chamou de "subjetividade inquieta" (CHIRPAZ, 1998, p. 77), traduz essa experiência de deslocamento, na qual "la terre s'ouvre jusqu'aux abîmes", como escreveu Blaise Pascal. Os antigos trágicos gregos, Esquilo e Sófocles, 
a narrativa de Jó - obra para qual Dostoiévski dispensou profunda devoção religiosa - representam uma forma de subjetividade trágica que articula uma narrativa consciente de seu próprio deslocamento do mundo. Deslocamento também experimentado por uma tradição trágica moderna, que ganhou uma espécie de unidade nos escritos de Shakespeare, Pascal, Kierkegaard, Nietzsche e Dostoiévski, onde encontramos uma voz comum que, emergindo da diversidade de suas obras, testemunha o nascimento de uma subjetividade que se expressa em uma "inquietude" que reclama por si e pelo seu próprio destino.

Neste artigo, procuramos compreender Dostoievski como um pensador religioso e como artista, demonstrando como os caminhos da sua escritura promoveram uma intrínseca conexão entre arte e realidade, conseguindo encontrar, a partir da "totalidade concreta do ser", os conteúdos que deram forma e vida as suas tragédias. Partindo das eqüipolências de um ego totalitário que passou por um vertiginoso caminho de autoconhecimento, Dostoievski nos coloca diante de uma reflexão religiosa que procurou expor os intestinos de um mundo despedaçado e a incontornável condição de uma consciência presa aos mecanismos [irracionais] de uma natureza que anula toda e qualquer forma de "solidez ontológica da existência" (NEGRI, 2011, p. 142). O encontro com o vácuo, metáfora que encontramos para traduzir a perenidade de um negativo que só conduz ao nada, organiza os contornos de uma reflexão que instaurou uma lucidez que se libertou de uma "visão banal" da vida e da condição humana, que, invariavelmente, "flutua sob a superfície das coisas" (DOSTOIEVSKI, 2000, p. 409). 


\section{0 real é monstruoso}

Em um dos raros textos onde Dostoiévski escreveu em primeira pessoa sobre suas convicções religiosas, encontramos uma reflexão que nos ajuda a aprofundar nossa compreensão acerca da sua trágica percepção da existência. Meditação diante do corpo de Marie Dimitrievna é um escrito que nos coloca diante das urgentes questões existências vividas por Dostoievski diante do cadáver de sua primeira esposa. Escrito em 16 de Abril de 1864, portanto no mesmo período em que escrevia as suas Memórias do subsolo, suas reflexões nos levam ao coração das questões que estiveram presente em toda a sua obra madura. A cena do corpo frio e inerte reflete a impotência da vida diante da mecânica impiedosa da natureza, que conduzirá Dostoiévski a iniciar sua meditação com a pergunta que "desde a aurora da consciência humana tem atormentado a humanidade em face da morte" (FRANK, 2002, p. 409): "Macha repousa sobre a mesa. Tornarei eu a ver Macha?" (DOSTOIEVSKI, 1973). A sua dúvida e horror metafísico deram forma a uma meditação que se tornou fundamento do protesto trágico que encontramos em seu exercício literário, fazendo com que uma indiferença ou "resignação estóica" presente nos diversos racionalismos - desprovidos de vocabulário para tratar de questões malditas como o sofrimento diante da morte -, desse lugar a uma reflexão religiosa que procurou transcender e confessar os limites da simples razão. Como escreveu Joseph Frank, o que Dostoiévski experimentou diante do corpo inerte de sua esposa foi o que também vivenciou em outros momentos de sua vida, como o momento da farsa de sua execução promovida pelo Czar e nas cenas de horror metafísico tematizadas no seu trágico O Idiota (FRANK, 2002, p. 410). A dúvida trágica traduz "um terrível sentimento de incerteza" e de "repulsa diante do desconhecido", que se recusa, em um ato de insubordinação trágica, a "tornar-se um punhado de pó” (FRANK, 2002, p. 411). Sua recusa quis superar os limites de um materialismo, e sua reflexão religiosa abriu espaço para a erupção do mal e da dor, invariavelmente ocultado e deixado sob silêncio dentro do mundo racionalizado da filosofia (PAREYSON, 1998). 
Imerso em agonia, Dostoiévski dirige seu arsenal contra um racionalismo teológico e filosófico que, sutilmente, camufla os intestinos do mundo na forma de teodiceias, bem como contra um materialismo que nega ao indivíduo a possibilidade de articular seu protesto diante do vácuo de sentido da existência, pois, reconciliados estoicamente, o indivíduo e a inércia da natureza, essa tradição de pensamento abstrai e nega, também de maneira sutil, o escândalo do mal no qual estamos todos mergulhados. É neste sentido que podemos compreender a sentença que encontramos na conclusão de sua Meditação: "A doutrina dos materialistas: inércia universal e mecanismo da matéria, seu significado é a morte" (DOSTOIEVSKI, 1973, p. 61). Em seu texto, entrevemos a intuição que percebeu a aliança entre o materialismo científico e a superação da questão religiosa, e a decorrente morte do homem e do seu direito a uma resistência ontológica que, para lembrarmo-nos de Camus, "não receia o ridículo de interrogar-se sobre o sentido da vida". Seu protesto desnuda a negatividade da existência e a banalidade de um mundo que procura recalcar o mal e a dor com os requintes e a serenidade dos pragmatismos da razão. A morte do homem, decorrente do silenciamento de sua subjetividade trágica, se expressa como privação da pergunta por sentido, imposta por um niilismo racional que é o lugar próprio de uma existência pragmaticamente sustentada (PONDÉ, 2003, p. 25). Luige Pareyson acenou para a diferença entre uma forma de niilismo racional e um pensamento que tem suas raízes na experiência patética de um temperamento trágico. Para Pareyson,

aos olhos do niilismo reconfortante, a questão do sentido da vida não possuiu nenhum sentido: o mundo não é absurdo nem não absurdo. $\mathrm{O}$ pensamento trágico, em revanche, não se contenta com esse não lugar, que dissipa a seriedade da vida dentro da despreocupação do vivido (PAREYSON, 1998, p. 210).

É contra esse "não lugar, que dissipa a seriedade da vida" que Dostoiévski dirige o seu protesto, e o faz alicerçado em um vocabulário religioso capaz de abrir espaço para a erupção dessas questões malditas, sempre recorrentes ao homem 
que se encontra diante da corruptibilidade da natureza: o mal, o sofrimento e a questão da existência ou da não existência de Deus. Julgo que o fenômeno moderno observado por Jacques Derrida, no seu Foi et Savoir, sobre a experiência do cristianismo como "morte de Deus" e sua aliança com o "capitalismo técnicocientífico" (DERRIDA, 2000, p. 23), não esteja distante do problema levantado por Dostoiévski, que enfrentou um materialismo científico niilista que procurou superar a negatividade da existência a partir de mecanismos racionais, políticos e científicos, libertando-se da intratável antinomia religiosa que o pensamento trágico insiste em afirmar contra um racionalismo de caráter utilitarista e pragmático.

As saídas de uma metafísica racionalista - que justifica a totalidade e promove o amparo de sentido da existência nas "astucias da razão" (Hegel) ou nas "astucias da natureza" (Goethe) ${ }^{1}$ - e o questionamento dos limites de um niilismo racional, que aniquila da alma toda angústia transcendente e ajusta a vida aos esquemas pragmáticos do mundo, dá lugar a uma experiência que "desconstrói as máscaras de um pragmatismo cotidiano" (LEOPOLDO E SILVA apud PONDÉ, 2003). Este movimento descobre o vazio da existência, tornando-se princípio de uma experiência que desorganiza os fundamentos ontológicos de uma metafísica religiosa ou racionalista. A hierofania trágica promovida por tal experiência provoca um esvaziamento ontológico, libertando o homem da idolatria do conceito, abrindo sua existência para a consciência profunda do seu vácuo (PONDÉ, 2003). Este princípio de desontologização que, no percurso do pensamento filosófico religioso moderno vai de Pascal a Nietzsche, encontrou em Dostoiévski uma tradução literária que está na base de seu pensamento religioso. A questão “Deus” [conceito chave no vocabulário ocidental para pensar a questão do divino] surge na trajetória religiosa de Dostoiévski no momento em que os limites da natureza humana apresentam a sua face mais demoníaca, e o problema do mal, levado ao esgarçamento, dissolve os esquemas de sentido de uma razão teórica e prática. $\mathrm{O}$

\footnotetext{
${ }^{1}$ Para Karl Löwith, “Hegel como Goethe [...] a diferença de suas mediações está em que Goethe concebe a unidade partindo da natureza observada e Hegel partindo do espírito histórico. A essa diferença corresponde o fato que Hegel reconhece uma "astucia da razão" e Goethe uma "astucia da natureza". (LÖWITH, 1969, p. 24).
} 
advento do negativo - representado pela natureza inerte do cadáver de sua esposamarca a questão religiosa para o autor de Memórias do subsolo, e toda a sua discussão com o materialismo do século XIX teve como ponto de partida uma consciência religiosa e trágica que soube tematizar os limites da natureza e da razão.

Luigi Pareyson demonstrou as formas de paganismo presente no universo moderno que investido de uma ansiedade por reconciliação, procurou privar o mal, o sofrimento, e a morte de sua dimensão escandalosa. Assim, Pareyson constatou que a) o mal reduzido a um puro sentido de falta, é facilmente superado e não requer um doloroso caminho de expiação b) o sofrimento, se o considerarmos como administrado por uma necessidade, pode ser facilmente suportado, pois apesar de sua dureza e ferocidade, a resignação estoica não é absolutamente difícil c) a morte, apresentada como um evento natural sem esperança de sobrevivência, como um episódio necessário da vida, pode facilmente ser serena. Assim, em um tom afinado com as intuições religiosas mais caras a Dostoiévski, Pareyson afirma que

o niilismo consolador e o ateísmo reconfortante estão engajados em um caminho de minimização absoluta. Mas o mal, o sofrimento e a morte, somente mostram seu aspecto trágico na presença de Deus e só podem ser percebidos em todo seu horror se Deus existir (PAREYSON, 1998, p. 210).

A opinião de Pareyon [que está entre os mais sofisticados interpretes filosóficos de Dostoievski] traduz o cerne do pensamento trágico-religioso de Dostoiévski, demonstrando que a recusa do problema religioso pode trazer consigo um elemento que procura subtrair, a partir de mecanismos racionais, o escândalo do mal que atravessa a condição humana, criando uma espécie de homens convencidos de que os poderes da razão podem subtrair a angustia presente na suspensão absoluta provocada pela experiência do negativo. Para Pareyson, 
Existe um ateísmo reconfortante para as novas "belas almas", aquelas que sob a aparência de anticonformismo, possuem um desejo de despreocupação da existência, tornando-se afeitas a uma vida doce, pacifica, sem inquietudes e nem tormentos; da mesma forma, existe um cristianismo para os novos espíritos fortes, que não possuem nenhuma ilusão acerca da negatividade da vida e procuram manter uma consciência lúcida, desencantada e livre. Existe ainda um cristianismo de "belas almas", mas, em nossos dias, o não crente ainda parece mais desejoso de um pensamento edificante e consolador que o crente. Há, entre nós, uma nova teodiceia, uma teodiceia às avessas, que é aquela que proclama a inexistência de Deus. Descobriu-se que a inexistência de Deus pode tornarse uma comodidade, pois sem Deus, o mundo perde todo o seu caráter angustiante; sem Deus, toda distinção entre o bem e o mal desaparece. O verdadeiro cristão sabe que Deus não pode ser uma certitude metafísica, que poderia ser atingido pela razão demonstrativa, mas que sua existência é de uma urgência inelutável: é um Deus difícil, que nos obceca e não nos dá sossego, que, como disse Dostoiévski, nos espera na virada da esquina (PAREYSON, 1998, p. 211).

A abstração racionalista que recalca o negativo, ou faz dele um momento dialético de superação das aporias da história (Hegel), quis submeter à condição humana aos mecanismos da razão e negar que existe dentro da natureza e dentro do obscuro da consciência humana, forças ocultas, ingovernáveis, capazes de desequilibrar o espírito ou destruí-lo (PAREYSON, 1998, p. 211). O "niilismo racional", como expressão de um pragmatismo sociopolítico moderno, quis alcançar uma espécie de "funcionalidade mundana" (LEOPOLDO E SILVA apud PONDÉ, 2003), que retirou do homem o incômodo do transcendente e, desta forma, minimizou o horror metafísico (KOLAKOWSKI, 1989) de uma visão trágica, proporcionando uma existência tranquila e privada de pathos. Para uma consciência trágica, imersa na desordem da existência, a "questão Deus" aparece como uma necessidade, não como uma certitude. Distante das celebrações da imanência, e tragicamente afetada pelas fricções de uma história que celebra a força de homens extraordinários, a alma trágica firma-se em uma atitude religiosa que se recolhe do espetáculo do mundo, direcionando seu "olhar sobre o mundo devastado não só pela desgraça, mas principalmente pelo enfrentamento dela" (PONDÉ, 2004, p. 177). O pathos trágico é promotor de uma atitude religiosa desconstrutora dos fundamentos da imanência e das formas sociais de vida que buscam se sustentar em uma ontologia natural, provocando uma experiência que se manifesta como 
enfrentamento religioso da contingência. A tese de Pareyson, para quem a "descoberta da inexistência de Deus tornou-se uma comodidade, pois, sem Deus o mundo perde o seu caráter angustiante”, é o foco da crítica religiosa do autor de Memórias do Subsolo, antecipando um niilismo contemporâneo que experimentou a "agressividade da contingência", pois sabia, antes do insensato de Nietzsche, que, sem Deus, toda distinção do bem e do mal desaparecem, e a angústia, como o desespero, tornam-se elementos estranhos à banalidade dos afazeres humanos, imersos em um sofisticado pragmatismo cotidiano. O pathos provocado pela constatação nietzschiana da "morte de Deus" e a indiferença alegre "daqueles que não acreditavam em Deus" demonstram a aniquilação da angústia experimentada pelos habitantes de um "palácio de cristal” moderno.

Nicolai Berdiaev, um dos herdeiros mais sofisticados de Dostoievski, considerando a distinção entre a angústia e o medo, afirmou que,

o medo possui razões, ele é provocado por um perigo, como experimentado objetivamente no mundo empirico. Mas a angustia, ela é experimentada diante do mistério do ser e do não ser, diante do abismo da transcendência, diante do desconhecido (BERDIAEV, 1946, p. 68).

Para Berdiaev, “diante da morte, experimentamos não somente um temor provocado por este acontecimento empírico, mas também uma angústia que inspira uma experiência de caráter transcendente" (BERDIAEV, 1946, p. 68). A meditação religiosa de Dostoiévski diante do cadáver de sua primeira esposa foi um protesto religioso que desnudou suas convicções mais íntimas. Imerso em uma angústia que transcende as preocupações banais de uma existência pragmática, distante de um estoicismo indiferente ou de uma weltanschauung romântica que quer dar sentido a inércia da natureza a partir das abstrações de um racionalismo materialista, Dostoiévski elaborou uma reflexão religiosa que foi produto de um radical processo de desontologização da vida, que se tornou incapaz de resistir ontologicamente a dissolução impiedosa da natureza. Nenhum humanismo materialista seria 
capaz de construir uma ontologia que resistisse à força da inércia; e é à luz dessa convicção que nasceu um pathos religioso que proclama Deus como uma necessidade inelutável, como experiência de redenção de uma natureza despedaçada pelo mal. Em seu esgarçamento completo das condições empíricas do homem, a meditação conclui que "a doutrina da verdadeira filosofia é a abolição da inércia, quer dizer, o pensamento como centro e síntese do universo e de sua forma aparente, a abolição da matéria, ou seja, Deus, a vida eterna” (DOSTOIEVSKI, 1973, p. 62).

Um dos pontos altos da Meditação está em sua análise religiosa da natureza humana. Sua reflexão oferece uma antropologia teológica reveladora de um estado de profunda consciência de si, uma percepção de si mesmo e da condição humana que marcou significativamente sua produção literária madura. Foi neste período em que concluiu a primeira parte de sua obra Memórias do Subsolo, e as intuições deste texto fundador da literatura moderna estão explicitamente presentes em sua Meditação. Imediatamente após se perguntar "voltarei um dia a ver Macha?”, Dostoiévski faz um diagnóstico da natureza humana que se identifica com a sua própria relação com Marie Dimitrievna: “amar um ser humano como a si mesmo, segundo o preceito do Cristo, é impossível. A lei da personalidade nos liga sobre a terra, o eu torna-se um obstáculo" (DOSTOIEVSKI, 1973, p. 60). Toda meditação é perpassada pelo que Dostoiévski reconheceu como a "lei da personalidade", demonstrando uma tematização da condição humana que se aproxima, inquestionavelmente, de uma antropologia paulina. Para Dostoiévski,

O homem sobre a terra inclina-se para um ideal oposto a sua natureza. Quando o homem não realiza o cumprimento da lei, que consiste em orientar-se para esse ideal, dito de outra forma, quando ele não oferece o seu eu em sacrifício de amor aos homens ou por outro ser (Macha e eu), ele experimenta um sofrimento e dá a esse estado o nome de pecado. Dessa forma, o homem deve constantemente experimentar um sofrimento que é contrabalanceado por um prazer paradisíaco que procura o cumprimento da lei, ou seja, o sacrifício. É nisto que se estabelece o equilíbrio terrestre. De outra forma, a vida na terra seria desprovida de sentido (DOSTOIEVSKI, 1973, p. 62). 
Sua reflexão traduz uma antropologia teológica que reconheceu o estado cindido do ser humano, sua trágica condição de ambiguidade que experimenta um ego imerso em concupiscência. A consciência do pecado que caracteriza o homem na natureza é signo dessa angústia trágica, uma angústia da finitude que marcou indelevelmente o espírito judaico-cristão de São Paulo. Expressão de uma sensibilidade que questiona as formas de reconciliação naturalistas [um reflexo do orgulho pagão] a antropologia paulina desconstrói as virtudes autossuficientes da natureza humana, que para lembrarmos as reflexões de Willian James, caracterizam-se por "tudo aquilo sobre o que o paganismo, o naturalismo e o legalismo basearam sua confiança” (JAMES, 2006, p. 369). Na meditação encontramos a voz de uma consciência cindida que clama por redenção, traduzindo o que escreveu Bruno Forte em seu texto sobre Dostoiévski e Henri de Lubac: “a existência trágica evoca misteriosamente um advento de graça, que nos liberta do esgotamento de existir...” (FORTE, 2003, p. 103). A Meditação dostoievskiana é um luto que concentra toda a sua força reflexiva nas “devastações do egoísmo”, na descoberta dessa inclinação subterrânea que dilacera todos os ideais proclamados pelos lábios dos profetas de uma natureza virtuosa e reconciliada. Para Dostoiévski, essa consciência cindida se expressa em todas as dimensões sociais da vida e instituições como o casamento, a família, por mais que representem "a coisa mais sagrada para o homem sobre a terra", representam um mundo objetivo que reflete a "lei da natureza", "um estado anormal" egoísta, no pleno sentido desta palavra (DOSTOIEVSKI, 1973, p. 61). Sua reflexão acena para uma visão apocalíptica que foi elemento determinante nos cristianismos originários no primeiro século. Como nos lembra Joseph Frank, "o cristianismo primitivo não tinha o casamento e a família em tão alta estima, e Dostoiévski poderia muito bem ter citado tanto as palavras de Cristo quanto as de São Paulo para apoiar seus pontos de vista” (FRANK, 2002, p. 417). Importante notarmos a antinomia que perpassa o pensamento dostoievskiano e sua aguda intuição sobre os mecanismos inconscientes que governam o comportamento do homem. Como um São Paulo moderno, ele analisa as ambigüidades estruturais da condição humana, descobrindo a contradição 
trágica, o movimento perverso que existe nos extratos mais profundos da consciência. Esta angustia, como sabemos, não alcança sentido para uma consciência, digamos, pós-pascaliana, desprovida de vocabulário religioso e imersa nos sofisticadíssimos jogos pragmáticos da finitude.

Meditação diante do corpo de Maria Dimitrievna é um texto de valor inestimável para o cânon dostoievskiano. Nele encontramos muito mais do que o artista mergulhado nas intermináveis questões polifônicas e nos deparamos com o pensador religioso que foi "cristão à sua maneira", o qual soube tematizar as angustias de um homem que organizou os contornos de uma real escritura de si, esboçando a autoimagem despedaçada e as dúvidas de uma consciência que se viu confrontada pelos abismos de uma natureza cega, desprovida de ordem e traços divinos, onde as desqualificações incontornáveis dos "desmascaramentos modernos" foram levadas ao esgarçamento, abrindo o vácuo que deu voz às confissões mais intimas de uma alma trágica. Para Joseph Frank,

em nenhum outro lugar [Dostoievski] esboça de forma tão explicita os traços gerais de seu universo trágico, onde o homem trava uma luta sem fim para alcançar um ideal contrario às instigações de seu ego individual e onde o egoísmo, não só é tradicionalmente um mal como também está corporificado nesses pilares reverenciados pela coesão social que são o casamento e a família. Em nenhuma outra pagina saída de sua pena, Dostoiévski lança tamanha torrente de luz sobre alguns dos cantos mais escuros de seu universo artístico (FRANK, 2002, p. 423).

\section{Quem saberá discernir o real e aprofundá-lo?}

Em um dos contos mais surpreendentemente trágicos de Dostoiévski, encontramos uma reflexão que, apesar de não estar diretamente relacionada, aproxima-se bastante de sua Meditação diante do corpo de Marie Dimitrievna. A Dócil (DOSTOIEVSKI, 2003), traduzido também para a língua portuguesa como Uma Doce Criatura, "descreve os pensamentos de um marido que anda de um lado para o outro do quarto onde estão os restos mortais da esposa, que cometera 
suicídio atirando-se de uma janela com um ícone preso na mão" (FRANK, 2002, p. 409). Neste comovente conto, encontramos o "realismo fantástico" de Dostoiévski, seu realismo "au sens le plus élevé”, capaz de desvendar o subsolo da natureza humana e a dinâmica de um ego preso a "lei da personalidade", reflexo incontornável do mecanismo desgraçado da matéria. Em nota introdutória, Dostoiévski intitula sua narrativa como "fantástica", ainda que ele mesmo considere sua obra "realista ao extremo" (DOSTOIEVSKI, 2003, p. 13). Neste jogo de conceitos literários, deparamo-nos com o método dostoievskiano, seu realismo fantástico, o qual, partindo de uma realidade extrema, foi capaz de acessar "os cantos mais escuros" da existência humana. Dostoiévski afirma não se tratar de uma simples "narrativa", nem mesmo de "memórias", e coloca diante do seu leitor um homem transtornado que "anda pelos cômodos da casa, falando sozinho", procurando desesperadamente encontrar sentido para a tragédia que lhe arrancou de seu mundo. Em um processo de tomada de consciência, "narrando a coisa, esclarecendo-a para si mesmo", o homem consegue encontrar "irrefutavelmente a verdade” (DOSTOIEVSKI, 2003, p. 13), o que o leva a uma completa situação de desespero. A conexão entre arte e realidade demonstra como o Dostoiévski, cronista do cotidiano, inspirou o artista (PASCAL, 1985, p. 245). O autor de A Dócil foi significativamente impactado pelo suicídio de duas jovens, entre elas a filha de A. Herzen, cujo suicídio representa a presença dessa "bile noire" que invade a alma e instala-se no coração de um sem número de homens e mulheres. Para Dostoiévski, "essa jovem envenenou-se, provavelmente porque sua alma havia sido esvaziada de toda fé na vida, porque estava cansada de viver" (DOSTOIEVSKI apud PASCAL, 1985, p. 245). O tom melancólico do cronista traduz essa dor da alma que não encontra sentido na existência: "mais olhai, o sol que brilha os brotos que se abrem: você está cansada, antes mesmo de ter vivido" (DOSTOIEVSKI apud PASCAL, 1985, p. 245). A pequena novela inspira-se no suicídio da segunda jovem, que saltara para a morte segurando firmemente um ícone da virgem em suas mãos. Esse suicídio submisso e trágico marcara-o profundamente. Para Dostoiévski, "seu suicídio foi dócil, submisso, sem murmúrio nem censura” (DOSTOIEVSKI apud PASCAL, 1985, 
p. 246), e essa imagem de um suicídio humilde obsedou-lhe a mente. Em uma de suas notas de trabalho, como nos revela Joseph Frank, assinalou, "a moça com o ícone”, demonstrando como esse fato o marcou e como projetava utilizá-lo como tema de um possível conto. Essa sensibilidade de cronista foi sintoma da sua rejeição de um olhar abstrato, de alguém que procurou refletir sobre a matéria bruta da vida e pensar a realidade empírica de homens e mulheres mergulhados em um cotidiano trágico. Como escreveu G. Steiner, "ele encontrava nos jornais uma confirmação de sua própria visão tencionada da realidade" (STEINER, 2006, p. 106). Escrevendo a Nikolai Strakhov, em 1869, Dostoiévski revela sua percepção sui generis da realidade empírica, demonstrando as bases fundamentais de sua escritura.

Eu tenho uma concepção pessoal do real (em arte), e aquilo que a maioria das pessoas chamam de fantástico e excepcional, constitui-se, muitas vezes para mim, a própria essência do real. As manifestações cotidianas e a visão banal das coisas, no meu ponto de vista, não podem ser consideradas realismo, sendo a verdade completamente o oposto disso. Em cada notícia de jornal, você se confronta com os fatos mais reais e os menos comuns. Para os nossos escritores russos, eles são fantásticos e, por isso, são negligenciados; no entanto, eles constituem a realidade, porque eles são fatos. Quem poderá notá-los, explicitá-los e descrevê-los? [...] Quem saberá discernir os fatos e aprofundá-los? (DOSTOIEVSKI, 2000, p. 437).

Em outra carta, desta vez ao seu amigo e confidente, Apollon Maikov, Dostoiévski nos mostra como sua literatura almeja encontrar, por meio do seu singular realismo, os mistérios impenetráveis do homem.

Eu tenho da realidade e do real uma concepção muito diferente daquela dos nossos realistas e críticos. Meu idealismo é mais real do que o deles. Senhor! Conte-nos um pouco, de maneira sensata, aquilo que todos nós, russos, experimentamos nestes dez últimos anos, acerca de nosso desenvolvimento espiritual, e, rapidamente, nossos realistas exclamarão que se trata de pura imaginação! No entanto, trata-se do mais autêntico, do mais puro realismo! Na verdade, este é o verdadeiro realismo, no sentido profundo, o deles apenas flutua sob a superfície. (DOSTOIEVSKI, 2000, p. 409).

Parte significativa dos scholars de Dostoiévski, como V. Ivanov e G. Steiner, compararam sua arte narrativa aos versos trágicos de Shakespeare, demonstrando como o seu realismo procurou ir além de uma "visão cotidiana e banal das coisas". 
Steiner escreveu que Dostoiévski "teria valorizado a comparação com Shakespeare" 2. Ele escrevia nas anotações de Os Demônios que o "realismo" shakespeariano como o seu próprio - não se restringia às meras imitações da vida cotidiana: "Shakespeare é um profeta, enviado por Deus, para nos proclamar o mistério do homem e da alma humana" (STEINER, 2006, p. 125). Para Dostoiévski, o que faltava no realismo de um Turguéniev ou de um Tolstoi, é que suas abordagens não possuíam a capacidade necessária para a penetração nos recônditos obscuros da alma humana, nas profundezas caóticas da existência (STEINER, 2006, p. 155).

A Dócil está entre os textos mais bem acabados de Dostoiévski (PASCAL, 1985, p. 246). Neste conto, encontramos uma antropologia religiosa fincada em uma interpretação trágica do cristianismo, que soube tematizar, impiedosamente, a realidade de um homem que não consegue ultrapassar a circularidade concupiscente de seu próprio egoísmo. Revelando-se como uma forte pulsão de destruição na ideia de subsolo, a pulsão titânica do ego cria, segundo Pierre Pascal, um "monstro isolado em seu egoísmo" (PASCAL, 1985, p. 246), e dá forma a uma realidade que isola radicalmente o homem em si mesmo, transformando-o em escravo do seu próprio orgulho. Dostoiévski nos mostra a realidade de um homem preso em sua própria concupiscência, incapaz de realizar um movimento de saída de si que ofereça espaço para a existência do outro. O marido da suicida é o narrador que passa por um processo de tomada de consciência de sua própria existência subterrânea, narrando a construção da sua relação com a esposa, agora morta. Encontramo-nos diante da uma antropologia triste, tematizando a condição de um homem que não consegue encontrar nada em si mesmo que fosse capaz de libertálo do mecanismo de dissolução perpetrado por seu próprio ego. O narrador recorda os mecanismos de poder que foram sendo estabelecidos em sua relação, e, sua consciência vai revelando as formas desse personagem tipo dostoievskiano que foi o homem do subsolo. Para Joseph Frank, o narrador é "uma variante do homem do

2 É interessante percebermos a radical oposição dos pontos de vista de Leon Tolstoi sobre a arte de Shakespeare. Para isso ver seu ensaio “sobre Shakespeare e o teatro (1906), In: TOLSTOI, L. Os últimos dias. São Paulo: Cia das Letras, 2011, p. 259-331. 
subsolo consumido pela amargura e pela raiva do mundo e levado a oprimir e esmagar os outros porque ele próprio se sentia oprimido e esmagado" (FRANK, 2007, p. 436). A lucidez com que narra a sua própria dissolução demonstra a consciência do vazio que instalou-se em seu ser, levando-o a um estado de desespero de alguém que se reconheceu mergulhado no horror do vazio. A agonia do narrador é, neste sentido, fundamental para compreendermos como Dostoiévski procura colocar uma consciência agônica em oposição a uma consciência niilista e póspascaliana, que se torna incapaz de enxergar como o ego está na raiz de todo o mal e reflete os mecanismos de uma matéria inerte. A consciência e a lucidez subterrânea são o início de um processo que leva o homem à consciência de sua própria negatividade. Esta espécie de homem "sabe que está perdido no infinito" e nos instantes em que "olha para dentro de si mesmo, não encontra nada" (PONDÉ, 2003, p. 202).

É com essa lucidez agônica que o narrador dá início ao seu monólogo em $A$ Dócil: “ é aí que está todo o meu horror, eu entendo tudo ” (DOSTOIEVSKI, 2003, p. 19). O conceito nietzschiano de ressentimento encontra eco na análise do subterrâneo realizada por Dostoiévski. Esse personagem tipo reflete um "sintoma de uma ânsia de poder que brota do desejo de compensar uma condição de inferioridade e subordinação" (FRANK, 2007, p. 438), e dessa forma, reproduz uma espécie de orgulho que, "na busca desesperançada de amor e compreensão", quis “impor a outra pessoa sua própria concepção de si mesmo" (FRANK, 2007, p. 438). O totalitarismo do ego emerge de uma consciência orgulhosa que não possui confiança em si mesmo, constituindo-se em um mecanismo de auto-afirmação promotor do aniquilamento da consciência alheia. Assim,

como procura o amor sem estar disposto a amar a si mesmo (até que seja tarde demais), como deseja obter amor por uma espécie de estupro psíquico através da dominação da consciência da outra pessoa, o resultado é exatamente o oposto do que deseja (FRANK, 2007, p. 438). 
O narrador, atestando sua incapacidade de entrega e de amor, afirma que,

desde o começo, ela se lançava a mim com amor.[...] Mas em todo esse arrebatamento dei logo de uma vez um banho de água fria. Em primeiro lugar, a severidade - foi debaixo da severidade que a trouxe para casa [...]. Fiz uso do orgulho, falava quase calado. É que eu sou mestre em falar calado, passei toda a minha vida falando calado e vivi comigo mesmo tragédias inteiras calado. Ah, pois eu também fui infeliz! Fui abandonado por todos, abandonado e esquecido, e ninguém, ninguém sabe disso. Porque me calava? Como um homem orgulhoso queria que ela descobrisse por si mesma, sem mim, que ela por si mesma adivinhasse acerca desse homem e o alcançasse! Ao aceitá-la na minha casa queria respeito total. Queria que ela rezasse fervorosamente diante de mim por meus sofrimentos - e eu merecia isso. Ah, sempre fui orgulhoso, sempre quis tudo ou nada! De inicio ela discutia, e como, mas depois foi se calando, completamente até, apenas arregalava demais os olhos, escutando, uns olhos assim grandes, atentos. E... e, afora isso, de repente entrevi um sorriso, desconfiado, silencioso, nada bom (DOSTOIEVSKI, 2003, p. 3637-39).

A tentativa de aniquilação da consciência da Dócil expressa um orgulho dominador que provocou um acirramento de egos que poderíamos aproximar da dialética hegeliana do mestre e do escravo, promotora de um círculo vicioso de destruição que tem seus fios de sentido amarrados em uma concepção de mundo que não reconhece senão a realidade do próprio ego, fechado completamente em uma solitude subjetivista. É dentro desta atitude dialética de egos que "a dócil se revolta" (Ibid, p.47) e, ao invés de "aceitar a sublimidade interior (na forma como ele o vê) do modo de vida do marido e curvar-se diante dele em admiração idolatrada, os dois se envolveram numa luta secreta de vontades" (FRANK, 2007, p. 439). Dostoiévski nos coloca diante de um tema que possui dimensões universais, $\mathrm{e}$ a dialética hegeliana do mestre e do escravo, tida como tema em A Dócil, aparece, aos olhos dostoievskianos, como tradução mais própria da história do mundo moderno. A concepção trágica acerca da natureza humana possui, nessa que é "uma das mais vigorosas novelas de desespero" (GROSMAN apud DAGOSTINI, 2008, p. 325), um acabamento que revela o tensionamento trágico de um solipsismo subjetivista que possui em si mesmo a medida de todas as coisas. A luta por reconhecimento presente na dialética hegeliana manifesta o reinado da violência 
individual, expressão totalitária do ego que foi levado aos limites mais extremos de uma experiência trágica. Dostoiévski soube discernir a violência totalitária de um solipsismo individualista, e seu homem do subsolo tornou-se o reductio ad absurdum de uma consciência fechada sobre si mesmo. Seu Raskolnikov, de Crime e Castigo, é a expressão política dessa consciência subjetiva que a razão moderna elevou in abstracto à esfera do universal, criando uma autarquia do pensamento $\mathrm{e}$ da vontade que transforma tudo ao seu redor em objeto (IVANOV, 2000, p. 51). O espírito trágico e anti-hegeliano de Dostoiévski possui a aguda consciência de que nenhuma reconciliação poderia brotar dessa luta por reconhecimento, e o narrador de $A$ Dócil experimentou essa dialética trágica que transforma todos os escravos em opressores, promovendo ad infinitum o mecanismo de um ego que não consegue firmar-se senão a partir do aniquilamento do outro. A lucidez da autoanálise do narrador o faz confessar que

\begin{abstract}
o passado sombrio e a reputação para sempre estragada da minha honra me oprimiam a cada hora, a cada minuto , e foi então que me casei. Por acaso ou não - não sei. Mas, ao trazê-la para casa, eu pensava estar trazendo um amigo, pois eu necessitava muito de um amigo. Mas via claramente que esse amigo, era preciso prepará-lo, completá-lo, e até mesmo dominá-lo (DOSTOIEVSKI, 2003, p. 65).
\end{abstract}

A ingenuidade romântica presente no pensamento hegeliano, proclamadora de uma dialética que colocaria fim ao reinado da violência individual, é um dos pontos fundamentais da crítica que encontramos no todo da obra de Dostoiévski. René Girard realizou uma interessante abordagem da dialética hegeliana do mestre e do escravo, demonstrando como existe uma continuação subterrânea dessa dialética da violência na tradição romanesca moderna, e, sobretudo, na obra madura de Dostoiévski. Segundo Girard,

A dialética hegeliana se situa num passado de violência. Ela esgota seus últimos efeitos com o advento de Napoleão. Já a dialética romanesca aparece no universo pós-napoleônico. Tanto para Stendhal como para Hegel, o reinado da violência individual esta encerrado; esse reinado deve dar lugar à outra coisa. Quando a violência e o arbitrário deixam de reinar nos relacionamentos humanos, a Befriedgung, a reconciliação, deve 
sucedê-los necessariamente. O reinado do Espírito tem que começar. Os hegelianos contemporâneos, e em particular os marxistas, não renunciaram a essa esperança. Eles simplesmente protelaram o advento do Espírito. Hegel, dizem eles, se enganou um pouco na data. O romancista, de sua parte, desconfia das deduções lógicas. Olha a seu redor e olha para dentro de si. Ele nada descobre que anuncie a famosa reconciliação. A vaidade Stendhaliana, o esnobismo proustiano e o subsolo dostoievskiano são a nova forma que assume a luta das consciências num universo de não violência física e, caso necessário, de não violência econômica. A força não passa da arma mais grosseira para as consciências predispostas umas contra as outras e corroídas por sua própria nulidade. Prive-as dessa arma, nos diz Stendhal, e elas fabricarão novas, que os séculos passados não souberam prever. [...] Seja qual for o sistema político e social que se consiga lhes impor, os homens não alcançarão nem a felicidade nem a paz com que sonham os revolucionários, nem a harmonia dos balidos com que se assustam os reacionários. [...] São as formas "subterrâneas ” da luta das consciências que os romancistas modernos estudam. Se o romance é o lugar da maior verdade existencial e social do século XIX, é porque ele é o único que se volta para as regiões da existência onde se refugia a energia espiritual (GIRARD, 2009, p. 137-138).

As "regiões da existência onde se refugia a energia espiritual". Esse é o lugar que busca acessar o realismo dostoievskiano, e sua pequena obra de arte, A Dócil, foi um desses instrumentos de aproximação da realidade que levou Dostoiévski aos bas-fond da alma humana. Encontrar o "homem dentro do homem", desnudar as suas convulsões psíquicas, perceber as pulsões incontroláveis que o determina, o movimento trágico que emerge das profundezas do seu ser, e, impiedosamente, demonstrar a aporia de sentido do universo onde este homem está jogado, eis o método teológico que reconhecemos em Dostoiévski. Sua metafísica trágica distancia-se das teodiceias históricas elaboradas pelos filósofos, pois sua sensibilidade foi capaz de intuir o desejo idolátrico e destruidor de um ego concupiscente. Nenhuma reconciliação histórica, aos moldes de uma escatologia imanente hegeliano-marxista, seria capaz de aplacar o reinado titânico de uma consciência violenta e egoísta. Na economia trágica de Dostoiévski, a violência e o arbitrário estarão sempre conduzindo subterraneamente as ações dos homens, tendo em vista estarem determinados por uma dinâmica concupiscente que revela a inércia trágica da matéria. A modernidade, para Dostoiévski, compreendida como 
concepção materialista do mundo, nos revela uma dinâmica e uma lógica de destruição que nenhuma teodiceia seria capaz de justificar. A escamoteação do trágico por uma teodiceia moderna racionalista, "où les voies de la providence s'accordent à bon compte avec le système du phiolosophe ou du théologien” (CLEMENT, 1978, p. 227), é incapaz de aplacar o grito de refutação de uma criatura que " olha a seu redor e para dentro de si, e nada descobre que anuncie a famosa reconciliação " (GIRARD, 2009, p. 137). Como confessou em sua Meditação, Dostoiévski sabia que a doutrina dos materialistas - inércia universal e mecanismo da matéria - significava a morte. Sua antropologia trágica foi suficientemente lúcida para perceber a incapacidade do homem em superar a violência totalitária e arbitrária do seu próprio ego. É dessa consciência trágica que surge o problema teológico em Dostoiévski, explorados no universo religioso presente em sua obra madura.

$A$ dócil representa uma das expressões mais acabadas do universo religioso de Dostoiévski, reconhecendo que o homem está imerso em um universo trágico e é incapaz, por si mesmo, de transcendê-lo. O processo de tomada de consciência do narrador, a descoberta do seu orgulho, egoísmo, vaidade, não foram capazes de criar um estado de reconciliação que pudesse estancar a ferida aberta pela manifestação de seu egoísmo totalitário. Todas as suas investidas de reconciliação não conseguiram alcançar o estado de isolamento que se abateu sobre sua dócil. Como analisou Dagostini, em todas as confissões, arrependimentos ou juras de amor eterno, o narrador almeja um estado de reconciliação em que pudesse alcançar um "status de herói romântico", procurando inverter a condição de outrora, reintegrando-se dessa forma na comunidade humana (DAGOSTINI, 2008, p. 70). Mas, ao contrário desse ideal romântico,

percebe-se o terror da heroína opondo-se ao êxtase dele: ha uma inversão aos estereótipos do romantismo, uma paródia invertida, que cria o trágico. O herói confessa seus ressentimentos, ódio pela sociedade e declara ser Krotkaia vítima de sua vingança. Reconhece o seu orgulho demoníaco, o seu egoísmo, mesquinhez, mentalidade utilitária, caráter difícil, natureza contraditória ao mundo existente, que, segundo Dostoiévski, é até gratuita, 
esquisita e inexplicável. Diante desse quadro de desespero do marido para reconquistar a felicidade perdida, Krotkaia promete-lhe fidelidade. [...] Neste acontecimento, revela-se o contraste entre o êxtase dele e o pânico de Krotkaia. A precipitação obsessiva do herói e a impotência da frágil heroína em corresponder a suas aspirações levam-na ao suicídio, o que gera uma oposição ao ideal romântico perseguido por Ele, representado no acontecimento anterior, " retorno ao casamento ". [...] O choque entre o real e o ideal, traço característico do romantismo, se da nela, pois Ela prefere a morte a viver sem ideal. Com a trágica morte da heroína, Ele, ao mesmo tempo em que revela toda a sua solidão, destitui todo o mundo ordenado, esbraveja contra todo o constituído e lança seu protesto desesperado e solitário. O que se constata no acontecimento final, " despedida ", é um quadro desolador: um homem profundamente isolado, cujas esperanças foram destruídas, tomado pela dor, tentando reter, o máximo possível, a mulher morta junto de si. O herói parece, por fim, ter suavizado seu conflito interior entre a autoconsciência e o orgulho, que se manifestou pelo egoísmo, mesquinhez, vaidade arrogância e autoafirmação, aproximando-se, assim, da verdade a que se permitiu chegar, através desse ato de autotranscendência do ego. Sob a tensão da narrativa, que reflete a penetração do herói na autoconsciência, que se dá no presente trágico a lembrança do passado, o herói converte-se num ser humano profundamente despedaçado, cindido e machucado (DAGOSTINI, 2008, p. 70).

A análise literária de Dagostine nos ajuda a perceber o topos da abordagem dostoievskiana, demonstrando como seu método literário cria um espaço para o esgarçamento do problema teológico. Seu "estereótipo do romantismo" como "paródia invertida que cria o trágico", soube tematizar uma antropologia religiosa desconstrutora dos ideais de reconciliação romântica, conduzindo a consciência do homem para um estado de lucidez, experimentando a dor de reconhecer-se imerso em seu próprio mal: "é aí que está todo o meu horror, eu entendo tudo" (DOSTOIEVSKI, 2003, p. 19). O grito trágico do narrador nasce dessa consciência cindida e despedaçada que sabe que a violência e o arbitrário não deixarão de reinar nos relacionamentos humanos, e que nenhum romantismo seria capaz de camuflar a realidade brutal da vida. Como escrevemos acima, o pathos trágico nasce da consciência lúcida de uma existência que se descobre desprovida de potência, fazendo eco ao grito de Jó, esse grito trágico que se contorce perante a indiferença ontológica da existência. A completa des-ontologização da vida presente na narrativa de Dostoiévski abre espaço para o esgarçamento do problema teológico, 
espaço que nenhuma ontologia positiva teria condições de superar. Em seu belo comentário de Jó, Antônio Negri nos fala sobre a experiência, ilustrada por Jó, de uma "consistência ontológica da potência", que se abre através da resistência ao sofrimento e possui uma determinação ontológica positiva que não conduz "ao nada", mas, ao contrário, eleva o homem a um estado de potência que é capaz de superar a sua "privação de ser" (NEGRI, 2011, p. 142). Contrariando os delírios de potencia spinozista de Negri, poderíamos afirmar que o herói de $A$ Dócil representa para o universo dostoievskiano a expressão mais profunda de uma "inconsistência ontológica da potência", que se tornou incapaz de encontrar a "solidez ontológica da existência" na "totalidade concreta do ser", (NEGRI, 2011, p. 142) que é pura contingência. O próprio Negri apresenta a radical "desmedida do mundo" experimentada por um sujeito mergulhado no sofrimento e deslocado dos sentidos da metafísica e do racionalismo moderno, confrontando-a com a "impostura hegeliana" e com a sua "fétida presunção de tudo controlar com o mecanismo dialético do Espírito" (NEGRI, 2011, p. 27). Conforme escreveu Negri,

não existe experiência que possa redimir a justificação do mundo, à exceção da descoberta de uma dor profunda e irresolúvel que é, em uma inversão extrema, causa e fim negativos do mundo. O mundo é o resultado de um trabalho negativo, a projeção de um mecanismo trágico, a definição de uma teologia negativa (NEGRI, 2011, p. 34).

Mas, para Negri, "existe a possibilidade de uma resistência ontológica" capaz de dar forma a uma "ontologia positiva" através de uma "ascese positiva" (NEGRI, 2011 p. 41), superando, de tal modo, a completa ausência de fundamentos de uma existência contingente. $\mathrm{O}$ exercício de Negri pode ser compreendido como uma postura materialista que procura, através da experiência do negativo, encontrar uma medida de valor na imanência e assim retirar da dor infinita do homem, "a possibilidade efetiva de construir valor, de ser a medida de tudo o que pode ser medido" (NEGRI, 2011, p. 41). É neste sentido em que podemos lê-lo, quando afirmou que 
o livro de Jó é um existencialismo sarcástico, que nega qualquer dialética através da experiência da dor e só conhece o ser como criação. Depois de Auschwitz e Hiroshima não há mais Deus - mas a necessidade humana de criar se mantém, integral e sempre mais urgente. É preciso desenvolver a potência depois de reconhecido (e dominado) o irredutível conteúdo passivo que ela contém, a dor da qual a potência é filha (NEGRI, 2011, p. 97).

Poderíamos afirmar que o narrador subterrâneo de Dostoiévski parte de onde o Jó "humanista e existencialista" de Antonio Negri para. O herói dostoievskiano percorreu toda a trajetória negativa que o levou ao existencialismo sarcástico que encontramos no Jó interpretado por Negri. Poderíamos afirmar que onde este último enxerga uma potência que revela o ser, "a consistência ontológica da potência", Dostoiévski reconhece a "inconsistência ontológica do negativo e da contingência", a inconsistência ontológica de uma forma de potencia que se estrutura nos restos de um romantismo pervertido e distorcido pelo egoísmo e pela vaidade. O herói de Dostoiévski olha ao seu redor - e para dentro de si - e não consegue encontrar a dignidade ontológica capaz de oferecer uma potência criativa que não esteja determinada pelo orgulho e vaidade. E, ao contrário do humanismo que exala da ontologia positiva do Jó inventado por Negri, que significa a "exclusão de qualquer relação com a teologia negativa” (Ibid, p. 142), Dostoiévski leva aos limites a inconsistência ontológica da natureza humana, levantando o problema teológico de um homem que é incapaz por si mesmo de encontrar um valor ontológico positivo, incapaz de desprender-se da realidade do mal de uma consciência concupiscente e imersa na tragédia. O grito trágico do narrador nasce de uma "mente" que "nunca foi tão lúcida" (DOSTOIEVSKI, 2003, p. 86), reverberando um estado de alma desesperado, o qual não encontra nenhum ponto de apoio na imanência. Poderíamos afirmar que o grito trágico do herói de $A$ Dócil “c'était le même cri sauvage avec lequel l'imagination tragique marqua pour la première fois notre vision de la vie. La même lamentation sauvage et nue sur l'inhumanité de l'homme et le gaspillage de l'homme " (STEINER, 1993, p. 345). A imaginação trágica desvenda os traços de precariedade do homem e promove uma 
desqualificação ontológica que descobre os intestinos de um mundo reduzido à inércia da matéria.

\begin{abstract}
Ah, a natureza! Os homens estão sozinhos na terra - essa é a desgraça! "Há algum homem vivo nesses campos?” - grita o bogatir russo. Também grito eu, que não sou bogatir, e ninguém dá sinal de vida. Dizem que o sol anima o universo. O sol vai nascer e - olhempara ele, por acaso não é um cadáver? Tudo está morto, e há cadáveres por toda a parte. Há somente os homens, e em volta deles o silêncio - essa é a terra! "Homens, amai-vos uns aos outros" - quem disse isso? de quem é esse mandamento? O pêndulo bate insensível, repugnante. Duas horas da madrugada (DOSTOIEVSKI, 2003, p. 87).
\end{abstract}

Neste enunciado, encontramos todo horror metafísico que salta da pena de Dostoiévski, traduzindo a experiência de uma consciência trágica incapaz de encontrar em si, ou fora de si, algo que pudesse aplacar o frio de indiferença que exala dos intestinos da matéria. Como escreveu J. Frank, "nada que Dostoiévski escreveu é mais pungente do que o grito de desespero do narrador no final, andando de um lado para o outro diante do esquife da "doce criatura", num momento em que o mundo inteiro tornou-se para ele a imagem de sua desolação" (FRANK, 2007, p. 441). A Dócil traduz um sintoma de desagregação niilista que fora próprio do talento cruel de Dostoiévski e de suas intuições religiosas mais subterrâneas. Nela, experimentamos seus anseios religiosos e vemos o advento da "questão Deus", que fere sua carne e atormenta sua existência, dando forma ao seu niilismo: "o niilismo apareceu entre nós, porque todos nós somos niilistas" (DOSTOIEVSKI apud BERDIAEV, 1940, p. 14). Nenhum espírito de reconciliação materialista foi capaz de aplacar sua extrema sede de eternidade e nenhum romantismo poderia camuflar a realidade escandalosa do mal que habita os subterrâneos da consciência. A experiência de decomposição da vida, da finitude, que grita por sentido e reconhecese imersa no desespero de não poder perceber um traço sequer de uma palavra divina, da voz aos tormentos de uma consciência que não procurou camuflar a aridez da alma moderna. 


\section{Conclusão: entre a dor e os narcóticos - os caminhos do abismo}

É sabido que o grito desesperado que ecoa das vísceras do herói dostoievskiano não encontra eco em um ateísmo reconciliado privado pathos e de vocabulário religioso. Um ateísmo reconfortante, como escreveu Pareyson, que se quer distante de toda inquietude e tormento. Essa forma de consciência, que denominamos pós-pascaliana, sabe que não há o que protestar, e que o destino do homem se encontra na reconciliação de sua consciência com as virtudes do mundo moderno: a técnica, a ciência e o capital. Assim, procura patética e euforicamente camuflar os incômodos de um pensamento trágico que insiste em revisitar essas questões malditas, contidas na ideia de Deus, do mal e do desespero e sofrimento diante da morte. É a partir de uma completa desontologização da existência, que colocou o indivíduo nu diante de um universo frio e sonambúlico, desprovido de todos os disfarces de uma variedade de romantismos e cosmopolitismo civilizados - sobretudo pela descoberta da ausência de dignidade ontológica desse próprio indivíduo, que descobre em si as mesmas pulsões irracionais da natureza que tanto o atormentam - é que emerge uma consciência trágica que experimenta a insuficiência radical da existência, dentro da qual nenhum valor humano autêntico pode ser encontrado, e todos os não-valores restam, por isso, possíveis, e também prováveis (GOLDMANN, 1997, p. 44).

Nicolas Berdiaev afirmou que "Dostoiévski sabia tudo que Nietzsche sabia, e alguma coisa a mais " (BERDIAEV, 1940, p. 68). Nele, encontramos o que Henri De Lubac e o próprio Berdiaev discerniram como um "espírito de profecia", que levou aos limites extremos a radicalidade do problema teológico do homem moderno. Para Lubac, Dostoiévski desvela os caminhos da consciência moderna como um profeta (LUBAC, 1998, p. 286), pois em sua consciência trágica e religiosa, encontramos concentrado, na forma de um tumor agudo, toda a crise do homem moderno. Nele, encontramos o olhar desesperado e niilista do desvairado de Nietzsche, seu grito de lucidez e tristeza lançado contra uma multidão de 
homens alegres que invadem as praças públicas, imersos nos afazeres banais de uma existência afogada em uma variedade de narcóticos que nos adormecem e nos libertam do assombro do mundo.

Não estou louco e não estou delirando de maneira nenhuma, ao contrário, a minha mente nunca foi tão lúcida - mas como assim ninguém em casa outra vez, outra vez dois cômodos, e outra vez eu sozinho com os penhores. Delírio, delírio, aí é que está o delírio! Eu a esgotei - foi isso! O que são agora as vossas leis para mim? De que me servem os vossos usos, os vossos costumes, a vossa vida, o vosso Estado, a vossa fé? Que me julgue o vosso juiz, que me levem para um tribunal, para o vosso tribunal público, e eu vou dizer que não confesso nada. O juiz vai gritar: "Cale-se, oficial!” E eu vou lhe gritar: "Quem dá a você agora o poder que me faça obedecer? [...] De que me valem agora as vossas leis? Eu me aparto". Ah, tanto faz! Cega, cega! Está morta, não ouve! (DOSTOIEVSKI, 2003, p. 86).

Na consciência trágica de nosso profeta russo encontramos o tormento pelo divino, a visceral consciência da realidade do mal, a radical desqualificação ontológica do homem e o grito febril e desesperado de uma alma que clama por redenção, tensionada por uma dúvida trágica que nos revela a impossibilidade material de dizer "Deus". Os fios que teceram a sua narrativa foram banhados pelo sangue de um homem que percorreu o deserto moderno à procura de Deus: "Eu procuro Deus", gritou o desvairado de Nietzsche, traduzindo a "questão" que torturou Dostoievski por toda a sua vida: "a existência ou não de Deus" (DOSTOIEVSKI, 200o, p.571). E são estes fios, marcados pelo sangue de uma alma que carregou consigo a dor do mundo e possuiu uma consciência transpassada pelo tormento divino, que teceram os contornos absurdos de uma existência trágica, que, como escreveu Bruno Forte, "evoca misteriosamente um advento de graça, que nos liberta do esgotamento de existir...” (FORTE, 2003, p. 103). 


\section{REFERÊNCIAS}

BERDIAEV, N. De l'esclavage et de la liberté de l'homme. Paris: Aubier, 1946.

BERDIAEV, N. O espírito de Dostoiévski. Rio de Janeiro: Editora Pan-americana, 1940.

BIANCHI, F. O tema da submissão feminina na novela Uma Criatura Dócil, In. GOMIDE, B. B. et al.(Org.). Caderno de Literatura e Cultura Russa. n. 2. São Paulo: Ateliê Editorial, 2008, p. 325-339.

CABRAL SUDÁRIO, J. Dostoiévski - Consciência trágica e crítica teológica da modernidade - subterrâneo, tragédia e negatividade teológica. 2012. 298f. Tese (Doutorado) - Pontifícia Universidade Católica do Rio de Janeiro, Departamento de Teologia, Rio de Janeiro.

CAMUS, A. Le Mythe de Sisyphe. Paris: Gallimard, 1994.

CHIRPAZ, F. Le tragique. Paris: P.U.F. Presses universitaires de France, 1998.

CLEMENT, O. Le Visage intérieur. Paris: Stock, 1978.

DAGOSTINI, N. A seleção e a construção de “Acontecimentos" no espetáculo em A Dócil. In: CAVALIERE, A. et al. (Org.). Caderno de Literatura e Cultura Russa. n. 2. São Paulo: Ateliê Editorial, 2008, p. 65-71.

DERRIDA, J. Foi et savoir. Paris: Éditions du Seuil, 2000.

DOSTOIEVSKI, F. Correspondance: tome 2. 1865-1873. Paris: Bartillat, 2000.

DOSTOIEVSKI, F. Duas narrativas fantásticas: a dócil e o sonho de um homem ridículo. São Paulo: Editora 34, 2003.

DOSTOIEVSKI, F. Méditation devant le corps de Marie Dimitrievna. Les Cahiers de l'Herne, Paris, n. 24, 1973, p. 60-62.

FORTE, B. À l'écoute de l'autre: philosophie et révélation. Paris: Éd. du Cerf : 2003. (Collection Philosophie et théologie).

FRANK, J. Dostoiévski: os efeitos da libertação, 1860-1865. São Paulo: Edusp, 2002.

FRANK, J. Dostoiévski: O manto do profeta, 1871- 1881. São Paulo: Edusp, 2007.

FRANK, J. Dostoiévski: Os anos de provação, 1850-1859. São Paulo: Edusp, 1999. 
GIRARD, R. Mentira romântica e verdade romanesca. São Paulo: $E$ Realizações, 2009.

GOLDMANN, L. Le Dieu caché: étude sur la vision tragique dans le pensées de Pascal et dans le théâtre de Racine. Paris: Gallimard, 1997.

IVANOV, V. Dostoïevski: tragédie, mythe,religion. Paris : Editions des Syrtes, 2000.

JAMES, W. La raison et la foi (1905). Archives de Philosophie, v. 69 ,n. 3, p. 369-374, 2006.

KOLAKOWSKI, L. Horreur Métaphysique. Paris: Payot, 1989.

LÖWITH K. De Hegel à Nietzsche. Paris: Gallimard, 1969.

LUBAC, H. Le drame de l'humanisme athée. Paris: Éd. du Cerf, 1998.

LUKÁCS, G. Métaphysique de la tragédie. In: LUKÁCS, G. L’Âme et les Formes.

Tradução Guy. Haarscher. Paris: Gallimard, 1974. (Colletion Bibliothèque de Philosophie). p. 241-275.

MÉSZÁROS, I. A obra de Sartre: busca da liberdade e desafio da história. São Paulo: Boitempo, 2012.

NEGRI, A. Jó: a força do escravo. [S.l.]: Record, 2011.

NIETZSCHE, F. O nascimento da tragédia ou helenismo e pessimismo. São Paulo: Companhia das Letras, 1992.

PAREYSON, L. Ontologie de la liberté: la souffrance et le mal. Paris: L'éclat, 1998.

PASCAL, P. Dostoïevski: l'homme et l'œuvre. Paris: Agora, 1985.

PONDÉ, L. F. Crítica e profecia: a filosofia da religião em Dostoiévski. São Paulo: Editora 34, 2003.

PONDÉ, L F. O método Deus. In: TEIXEIRA, F. No limiar do mistério: mística e religião. São Paulo: Paulinas, 2004. p. 175-204.

STEINER, G. La mort de la tragédie. Paris: Gallimard, 1993.

STEINER, G. Tolstoï ou Dostoiévski. São Paulo: Perspectiva, 2006. 